\title{
Effect of Milking Interval on Milk Secretion and Mammary Tight Junction Permeability in Dairy Ewes
}

\author{
V. Castillo, ${ }^{\star}$ X. Such, ${ }^{\star}$ G. Caja, ${ }^{* 1}$ R. Casals, ${ }^{*}$ E. Albanell, ${ }^{*}$ and A. A. K. Salama* $\dagger$ \\ *Grup de Recerca en Remugants, Departament de Ciència Animal i dels Aliments, Universitat Autònoma de Barcelona, \\ 08193 Bellaterra, Spain \\ †Sheep and Goat Research Department, Animal Production Research Institute, 12311 Dokki, Giza, Egypt
}

\section{ABSTRACT}

Twenty-four lactating ewes (Manchega, $\mathrm{n}=12$; Lacaune, $\mathrm{n}=12$ ) in mid lactation were used to assess the short-term effects of different machine milking intervals $(4,8,12,16,20$, and $24 \mathrm{~h})$ on milk yield, milk composition, and tight junction (TJ) permeability of mammary epithelia. Milk samples were analyzed for chemical composition, somatic cell count (SCC), and plasmin activity. Plasma lactose, and milk $\mathrm{Na}$ and $\mathrm{K}$ concentrations were used as indicators of TJ permeability. Milk accumulated linearly for up to $24 \mathrm{~h}$, showing a different rate according to the milk yield of the breed (Manchega, $38 \mathrm{~mL} / \mathrm{h}$; Lacaune, $87 \mathrm{~mL} / \mathrm{h}$ ). Milking interval affected milk fat content, which decreased markedly from 4 to $24 \mathrm{~h}$ in both breeds, but no differences were observed in milk protein content. The milk contents of casein, true protein, lactose, and total solids also varied according to milking interval. Values of SCC did not vary by breed $\left(175 \times 10^{3}\right.$ cells $/ \mathrm{mL}$, on average), showing the lowest $\log _{10}$ values for the 4 and 24-h milking intervals in both breeds. Plasmin activity in milk increased with milking interval until $20 \mathrm{~h}$ of udder filling in both breeds, and was poorly but positively correlated with SCC content $(r=0.39)$. Plasma lactose increased dramatically after $20 \mathrm{~h}$ of milk accumulation, indicating enhanced permeability of mammary TJ. As a result, an increase in $\mathrm{Na}$ concentration and in the $\mathrm{Na}: \mathrm{K}$ ratio, and a decrease in $\mathrm{K}$ concentration, were observed in the milk of Manchega ewes. On the contrary, no differences in $\mathrm{Na}$ and $\mathrm{K}$ concentrations in milk were detected in Lacaune ewes. In conclusion, our results proved that Manchega and Lacaune dairy sheep could maintain high rates of milk secretion during extended milking intervals in the short term, with no effects on udder health and few negative effects on milk yield. Increased TJ permeability, caused by the effect of udder filling, induced

Received December 4, 2007.

Accepted March 24, 2008.

${ }^{1}$ Corresponding author: gerardo.caja@uab.cat changes in milk composition that were more marked in Manchega than in Lacaune ewes.

Key words: milking frequency, tight junction, milk production, dairy sheep

\section{INTRODUCTION}

Southern European countries around the Mediterranean Basin account for more than $80 \%$ of the sheep milk collected in the world (Dubeuf and Le Jaouen, 2005). Ewe milk is mainly processed for cheese, which is in increasing demand, and therefore, dairy sheep are becoming an interesting economic alternative for farmers. Farms with high-producing dairy sheep usually machine milk large flocks and conduct twice-daily milking throughout lactation. As a result, more than half of total daily labor on dairy sheep farms is spent on milking (Marnet and McKusick, 2001), and milking is one of the main reasons that people are deterred from dairy sheep production.

The use of low-milking-frequency strategies could result in significant savings in labor and time spent in the milking parlor. McKusick et al. (2002) reported a reduction of approximately $27 \%$ of total milking time when milking frequency decreased from twice daily to thrice every $2 \mathrm{~d}$ from mid lactation through late lactation, without losses in milk yield. Mills (2004) also indicates the benefit of switching to once-a-day milking at mid lactation, to save money on staff and energy, in high-yielding dairy ewes. Nevertheless, previous studies in sheep showed that milk secretion increased when milking frequency increased (Negrao et al., 2001), and that a decrease in milking frequency from twice- to once-daily reduces milk yield and alters milk composition (Morag, 1968; Labussière, 1988; Nudda et al., 2002).

Differences in milk secretion in dairy species under extended milking intervals have been related to udder cistern size (Ayadi et al., 2003b; Salama et al., 2004) and tight junction leakiness (Stelwagen et al., 1994b, 1997). Tight junctions (TJ; zonulae occludentes) form part of the junctional complex between adjacent cells. 
They are semipermeable extracellular structures that surround cells in a gasket-like manner and are located in proximity to the apical domain of the cell (Stelwagen et al., 1995). They act as a barrier between adjacent epithelial and endothelial cells, thus preventing paracellular transport and maintaining the electrochemical gradient (Stelwagen et al., 1995). Permeability of TJ in lactating mammary glands increases with alveoli engorgement and switches to a leaky state after $18 \mathrm{~h}$ of milk accumulation in cows (Stelwagen et al., 1997), and after $21 \mathrm{~h}$ in goats (Stelwagen et al., 1994b). This allows the movement of milk components into the interstitial fluid and vice versa (Stelwagen et al., 1997) and results in a decrease in milk yield (Stelwagen et al., 1995) and milk secretion (Stelwagen et al., 1994b, 1997). Lactose is not produced in any organ other than the mammary gland (Kuhn and Linzell, 1970) and is not secreted basolaterally (Stelwagen et al., 1998), so its presence in blood can only be explained by its movement from milk into blood via leaky TJ. The use of plasma lactose as a reliable indicator of TJ permeability has been extensively studied in dairy cows and goats (Stelwagen et al. 1994b; 1995; 1997).

Although loss of TJ integrity may also be a key factor responsible for milk yield loss or milk component variation produced by milking omission in dairy ewes (McKusick et al., 2002; Nudda et al., 2002), no studies exist that prove that TJ open and if they do at what time this occurs in dairy sheep.

Extended milking intervals may also negatively affect milk composition and cheese yield as a result of increasing protease activity in milk. Plasmin (PL), a serine proteinase associated with $\mathrm{CN}$ micelles, is the most responsible for protease activity in milk (Bastian and Brown, 1996). Stelwagen et al. (1994c) and Kelly et al. (1998) reported significant increments in the activity of PL in milk during extended milking intervals, indicating that paracellular leakage may contribute to increased protease activity in milk. Thus, losses of mammary TJ integrity may not only compromise milk yield but also affect milk quality and cheese characteristics.

The primary aim of this study was to assess whether extended milking interval affects secretion of milk and milk components and if it compromises udder health. The secondary aim was to elucidate if tight junctions open, and, if they do, at what time this occurs, in 2 different breeds of dairy sheep markedly differing in milk yield and milk composition, by varying the length of the milking interval.

\section{MATERIALS AND METHODS}

The experimental procedures and animal care conditions were approved by the Ethical Committee of Ani- mal and Human Experimentation of the Universitat Autònoma de Barcelona (reference CEEAH 02/410).

\section{Animals and Management Conditions}

Multiparous ewes of 2 dairy breeds (Manchega, $\mathrm{n}=$ 12 ; Lacaune, $\mathrm{n}=12$ ) were used in a short-term experiment done in wk 11 and 16 of lactation. Ewes with symmetrical and healthy udders were chosen from the flock of the SGCE (Servei de Granges i Camps Experimentals) of the Universitat Autònoma de Barcelona (Bellaterra, Spain), on the basis of similar stage of lactation (70 \pm 3 DIM), milk yield by breed (Manchega, $1.11 \pm 0.09 \mathrm{~L} / \mathrm{d}$; Lacaune, $2.32 \pm 0.11 \mathrm{~L} / \mathrm{d}$ ), and SCC $\left(64 \pm 48 \times 10^{3}\right.$ cells $\left./ \mathrm{mL}\right)$ in the week previous (wk 10) to the start of the experiment. Absence of intramammary infections was checked by milk sample bacteriology according to Salama et al. (2003).

Ewes were allocated at wk 10 and 15 of lactation into 6 groups of 4 ewes each (Manchega, $n=2$; Lacaune, $\mathrm{n}=2$ ), and they were housed in a barn separate from the main flock to avoid conditioned stimulation of milk letdown between planned milkings as a consequence of milking machine operation. Ewes received constant illumination to minimize diurnal and nocturnal differences. They were offered a mixture of dehydrated alfalfa and fescue hay fed ad libitum, and were supplemented with $0.8 \mathrm{~kg} / \mathrm{d}$ of concentrate mixture pellets containing $1.75 \mathrm{Mcal}$ of $\mathrm{NE}_{\mathrm{L}} / \mathrm{kg}$ and $16.5 \% \mathrm{CP}(\mathrm{DM}$ basis).

Ewes were milked, after the weaning of their lambs (wk 5), in a double-12 stall parallel milking parlor (Westfalia Surge Ibérica, Granollers, Spain) equipped with recording jars and low-line milk pipeline. Milking was performed at a vacuum pressure of $42 \mathrm{kPa}$, a pulsation rate of 120 pulses/min, and a pulsation ratio of $50 \%$. The milking routine for the regular daily milkings (0800 and $1800 \mathrm{~h}$ ) as well as for irregular experimental milkings (daily schedule depending on experimental design; Table 1) included machine milking without udder preparation or teat cleaning, machine stripping, and teat dipping in an iodine solution (P3ioshield, Ecolab Hispano-Portuguesa, Barcelona, Spain) after cluster removal.

\section{Experimental Procedures}

The experiment consisted of a crossover with 6 milking intervals $(4,8,12,16,20$, and $24 \mathrm{~h})$ at random, replicated in wk 11 and 16 of lactation. Milking interval schedule during each experimental week was applied successively (total length $84 \mathrm{~h}$ ) without any period of washing-out between milking intervals. Milking order for groups of ewes was randomized to avoid 
Table 1. Experimental schedule for each studied group applied at wk 11 and 16 of lactation in Manchega and Lacaune dairy ewes

\begin{tabular}{|c|c|c|c|c|c|c|c|}
\hline \multirow[b]{2}{*}{ Group } & \multirow[b]{2}{*}{ Ewes, n } & \multicolumn{6}{|c|}{ Treatment order ${ }^{1}$} \\
\hline & & 1 & 2 & 3 & 4 & 5 & 6 \\
\hline 1 & 4 & $24 \mathrm{~h}$ & $4 \mathrm{~h}$ & $20 \mathrm{~h}$ & $8 \mathrm{~h}$ & $16 \mathrm{~h}$ & $12 \mathrm{~h}$ \\
\hline 2 & 4 & $4 \mathrm{~h}$ & $8 \mathrm{~h}$ & $20 \mathrm{~h}$ & $16 \mathrm{~h}$ & $12 \mathrm{~h}$ & $24 \mathrm{~h}$ \\
\hline 3 & 4 & $16 \mathrm{~h}$ & $4 \mathrm{~h}$ & $24 \mathrm{~h}$ & $8 \mathrm{~h}$ & $12 \mathrm{~h}$ & $20 \mathrm{~h}$ \\
\hline 4 & 4 & $20 \mathrm{~h}$ & $4 \mathrm{~h}$ & $12 \mathrm{~h}$ & $8 \mathrm{~h}$ & $24 \mathrm{~h}$ & $16 \mathrm{~h}$ \\
\hline 5 & 4 & $8 \mathrm{~h}$ & $4 \mathrm{~h}$ & $24 \mathrm{~h}$ & $12 \mathrm{~h}$ & $20 \mathrm{~h}$ & $16 \mathrm{~h}$ \\
\hline 6 & 4 & $12 \mathrm{~h}$ & $4 \mathrm{~h}$ & $16 \mathrm{~h}$ & $8 \mathrm{~h}$ & $20 \mathrm{~h}$ & $24 \mathrm{~h}$ \\
\hline
\end{tabular}

${ }^{1}$ Treatments included machine milking at intervals of $4,8,12,16,20$, and $24 \mathrm{~h}$.

possible carryover effects between milking intervals (Table 1).

The experiment started $(0 \mathrm{~h})$ after complete udder emptying by machine milking with the help of an i.v. injection of oxytocin (2 IU/ewe; Veterin Lobulor, Laboratorios Andreu, Barcelona, Spain) to remove residual milk. Thereafter, 1 of the 6 milking interval treatments was randomly applied, and the same udderemptying procedure by using oxytocin was repeated for each milking interval treatment.

\section{Sampling and Analyses}

Milk yield was recorded and milk samples were taken at each milking. For milk composition analysis, a sample of approximately $100 \mathrm{~mL}$ was collected and preserved with $\mathrm{K}_{2} \mathrm{Cr}_{2} \mathrm{O}_{7}(0.3 \mathrm{~g} / \mathrm{L})$ at $4^{\circ} \mathrm{C}$. Unhomogenized milk samples were analyzed for main milk components by a near infrared spectrometer (Technicon InfraAlyzer-450, Bran+Luebbe SL, Nordersted, Germany), according to Albanell et al. (1999). For SCC, samples were preserved with an antimicrobial tablet (Bronopol, Broad Spectrum Micro-tabs II, D\&F Control Systems Inc., San Ramon, CA) and kept at $4^{\circ} \mathrm{C}$ until analysis. The SCC was determined in the Dairy Herd Improvement Laboratory of Catalonia (ALLIC, Cabrils, Barcelona, Spain) using an automatic cell counter (Fossomatic 5000, Foss Electric, Hillerød, Denmark) previously calibrated for sheep milk.

Concentrations of $\mathrm{Na}$ and $\mathrm{K}$ in milk and of lactose in plasma were used as indicators of the leakiness of TJ. Milk samples $(10 \mathrm{~mL})$ were collected at each milking interval and frozen at $-20^{\circ} \mathrm{C}$ until analysis. Contents of $\mathrm{Na}$ and $\mathrm{K}$ were determined using inductively coupled plasma atomic emission spectroscopy in the Chemical Analysis Service of the Universitat Autònoma de Barcelona. To determine concentrations of plasma lactose for each milking interval, blood samples $(10 \mathrm{~mL})$ of 2 experimental ewe groups (Manchega, $\mathrm{n}=4$; Lacaune, $\mathrm{n}=4$ ) were individually collected immediately after milking from the jugular vein into hep- arinized tubes (Venoject, Terumo Europe, Madrid, Spain), refrigerated at $4^{\circ} \mathrm{C}$, and centrifuged at $490 \times$ $g$ for 15 min. Plasma was collected and stored at $-20^{\circ} \mathrm{C}$ until analysis of lactose by use of an enzymatic assay (Lactose/D-Galactose UV-method; Boehringer Mannheim/R-Biopharm, Darmstadt, Germany) according to Stelwagen et al. (1994a).

Finally, a third milk sample $(10 \mathrm{~mL})$ from each ewe at the first experimental period (wk 11) was collected and immediately frozen and preserved $\left(-80^{\circ} \mathrm{C}\right)$ until analysis of plasmin activity. Plasmin activity was determined according to Baldi et al. (1996). Assays were performed in duplicate by using $250 \mu \mathrm{L}$ of $0.1 M$ Tris$\mathrm{HCl}$ buffer (pH 7.4), 0.6 mM Val-Leu-Lys-p-nitroanilide (Bachem AG, Bubendorf, Switzerland), and $30 \mu \mathrm{L}$ of the milk supernatant. The reaction mixture was incubated at $37^{\circ} \mathrm{C}$ for $3 \mathrm{~h}$, and absorbance at $405 \mathrm{~nm}$ was recorded at 30-min intervals. A sample without supernatant served as a control for the detection of spontaneous breakdown of the substrate. The rate of $p$ nitroanilide formation was calculated from the linear portion of the absorbance vs. time curve. Plasmin was expressed as units, 1 unit being the amount of enzyme that produced a change in absorbance at $405 \mathrm{~nm}$ of $0.1 \mathrm{in} 60 \mathrm{~min}$.

\section{Statistical Analyses}

Data were analyzed by the PROC MIXED procedure for repeated measurements of SAS (SAS 9.1, SAS Inst. Inc., Cary, NC). The mixed model used included the fixed effects of milking interval $(4,8,12,16,20$, and $24 \mathrm{~h}$ ), breed (Manchega and Lacaune), group (1 to 6), period (wk 11 and 16), and order of treatment application (first to sixth); the random effect of animal nested within the group and breed; the interactions between breed and interval, period and interval; and the residual error. Plasmin activity analysis did not include the effect of period and their interactions in the model. Differences between least squares means were determined with the PDIFF test of SAS. Pearson correlation 


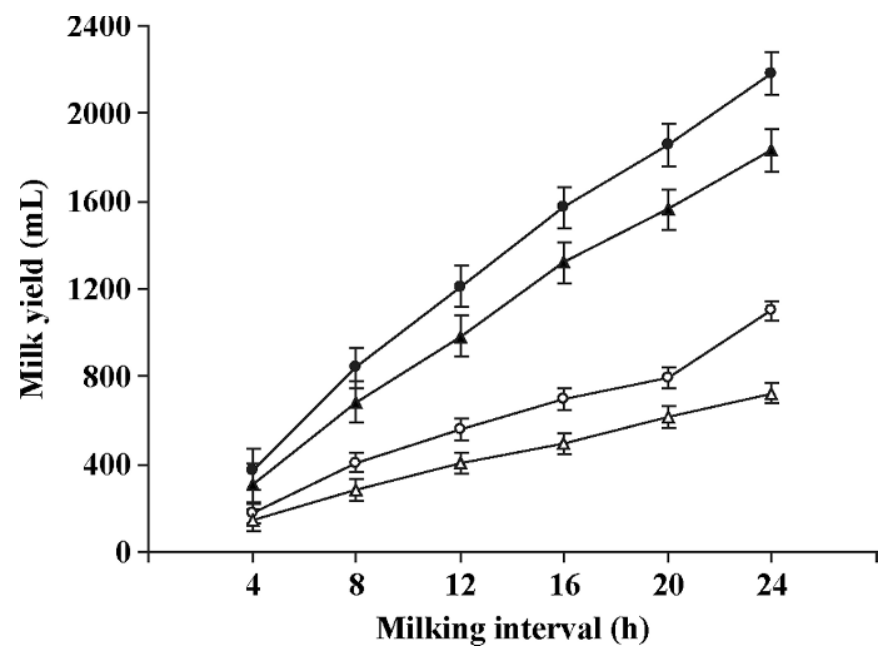

Figure 1. Effect of different milking intervals (4, 8, 12, 16, 20, and $24 \mathrm{~h})$ on milk yield at wk $11(\bigcirc, \mathbf{O})$ and $16(\triangle, \mathbf{\Delta})$ of lactation in Manchega (open symbols) and Lacaune (solid symbols) dairy ewes. Values are least squares means. Mean values within the same breed and lactation week differ at $P<0.05$; vertical bars represent SEM. Milk yield $(\mathrm{mL})=\mathrm{a} \times$ time after milking $(\mathrm{h})$; where $\mathrm{a}=44.0,31.1$, 94.3 , and 78.9 in $(\bigcirc),(\triangle),(\bullet)$, and $(\Delta)$, respectively; $R^{2}=0.99$ for all equations.

coefficients between measurements were also calculated. Significance was declared as $P<0.05$ unless otherwise indicated.

\section{RESULTS AND DISCUSSION}

\section{Milk Yield and Milk Secretion Rate}

Breed and period affected $(P<0.001)$ milk volume, with the Manchega ewes producing less milk than Lacaune ewes (averaged across all intervals, 0.53 vs. 1.23 $\mathrm{L}$, respectively). Milk volume was also affected $(P<$ 0.001 ) by milking interval and accumulated linearly $(P<0.05)$ up to $24 \mathrm{~h}$ in both breeds (Figure 1). Milk accumulation in the udder between milkings was described by the following equations $(\mathrm{y}=$ milk yield, $\mathrm{mL}$; $\mathrm{x}=$ time after udder milking, $\mathrm{h}$; average of both experimental periods):

$$
\begin{gathered}
\text { Manchega: } y=37.5 x\left(R^{2}=0.98\right) \\
\text { Lacaune: } y=86.6 x\left(R^{2}=0.99\right)
\end{gathered}
$$

The linear pattern of milk accumulation according to milking interval obtained in Manchega and Lacaune ewes agreed with earlier observations in other dairy ewe breeds (McKusick et al., 2002) and dairy goats (Salama et al., 2004). Milk accumulation rate depended on the milk yield potential of the breed $(P<$ 0.001), being greater in Lacaune than in Manchega

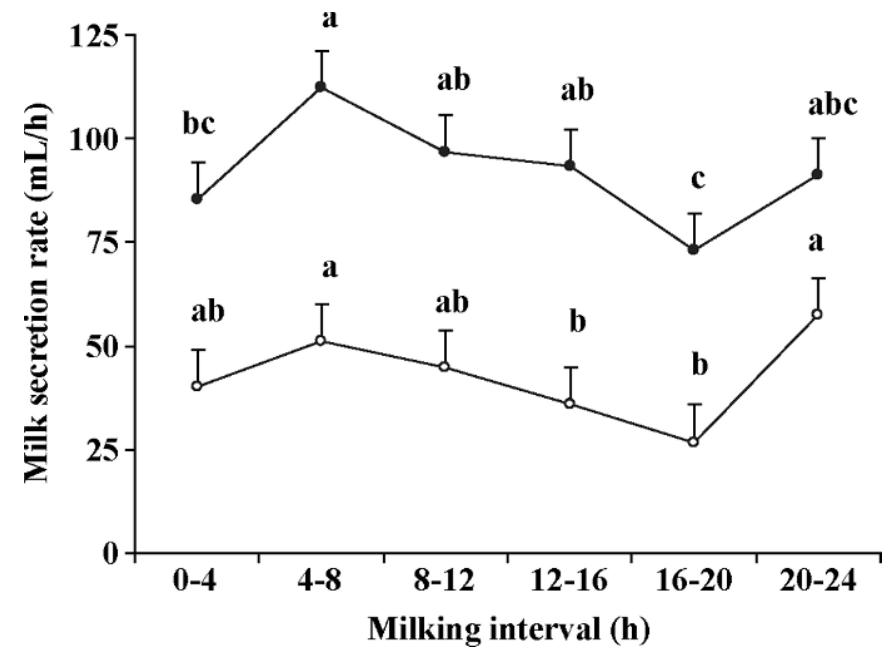

Figure 2. Milk secretion rates per milking interval in Manchega $(\bigcirc)$ and Lacaune $(\bullet)$ dairy ewes. Values are least squares means. ${ }^{\mathrm{a}-\mathrm{c}}$ Means within the same breed with different letters differ at $P<$ 0.05 ; vertical bars represent SEM.

ewes ( 87 vs. $38 \mathrm{~mL} / \mathrm{h} ; P<0.05$ ). In addition, the linear milk accumulation was greater $(P<0.05)$ in wk 11 than in wk 16 (Figure 1), showing that milk secretion rate decreased throughout lactation. In both breeds, the milk accumulation rate reached the greatest value with the 8-h milking interval and the lowest at the 20- to 24-h interval (data not shown), indicating a secretion rate saturation effect with time, as reported in dairy ewes (McKusick et al., 2002), goats (Salama et al., 2003), and cows (Knight et al., 1994; Ayadi et al., 2003a). The reduction of milk accumulation rate, after reaching the maximum value, was more marked $(P<0.05)$ in Manchega than in Lacaune ewes $(-20 \%$ and $-11 \%$, respectively, from the 8 - to 20 -h milking interval), suggesting that Lacaune ewes tolerate extended milking intervals better than Manchega ewes. Milk secretion rate reached the greatest values in the 4 - to 8 -h milking interval (Manchega, $51 \mathrm{~mL} / \mathrm{h}$; Lacaune, $112 \mathrm{~mL} / \mathrm{h}$ ) and decreased as time after milking increased (Figure 2). The lowest milk secretion values (Manchega, $27 \mathrm{~mL} / \mathrm{h}$; Lacaune, $73 \mathrm{~mL} / \mathrm{h}$ ) were obtained in the 16- to 20 -h milking interval.

Extended milking intervals in the present experiment were conducted in the short term, so reduction of milk secretion rate might be due to changes in TJ permeability (Stelwagen et al., 1995) and increments of intraalveolar pressure (Davis et al., 1999) or to the increase in the concentration of the putative feedback inhibitor of lactation in the mammary gland (Wilde et al., 1995) recently identified as serotonin (Hernández et al., 2008).

Although lower milk secretion rates were expected for the 20- to 24-h milking interval, our results (Figure 
2) showed a dramatic increase in milk secretion rate in Manchega $(+115 \%, P<0.05)$ and Lacaune $(+25 \%$, $P=0.06)$ after $20 \mathrm{~h}$. This unexpected increment for long milking intervals has not been previously reported and could be attributed to TJ leakiness, which might allow the flow of interstitial fluid into milk, generating an "apparent milk" secretion in both breeds. This increase in milk secretion after TJ opening agrees with the increase of milk secretion rate reported in dairy goats after inducing the disruption of mammary TJ with ethylene glycol-tetraacetic acid (Stelwagen et al., 1995).

Despite the expected entrance of interstitial fluid into milk as a result of TJ opening in both breeds (as discussed later), the increase in milk secretion rate for the 20- to 24-h milking intervals was less evident in Lacaune than in Manchega ewes. Udders with large cisterns produce more milk and are more tolerant to longer milking intervals in ewes (Labussière, 1988; Rovai, 2001), goats (Salama et al., 2003), and cows (Knight and Dewhurst, 1994). Therefore, damage of TJ, and probably of mammary epithelial cells, should be less marked in Lacaune ewes, which are characterized by larger cistern volume and greater cistern milk fraction than Manchega ewes (68 vs. 53\%, respectively; Rovai, 2001).

\section{Milk Composition}

Percentages of milk components (Table 2), except lactose, were affected by breed $(P<0.001)$. Early research on comparison of Manchega and Lacaune dairy ewes (Such et al., 1995; Rovai, 2001) reported that milk of Manchega ewes contains more fat and protein than milk of Lacaune ewes.

In the short-term, milking interval affected $(P<$ 0.05 ) the percentages of fat, $\mathrm{CN}$, true protein, lactose, and TS in milk. Milk fat content was the most markedly affected component in both breeds, decreasing ( $P$ $<0.05)$ with longer milking intervals. These results are in accordance with the previous observations of McKusick et al. (2002) in a short-term experiment also done in dairy ewes. Changes in fat content according to milking interval are related to the regulatory mechanisms for secretion of large and high-viscosity milk fat globules relative to the components in the aqueous phase of milk (Davis et al., 1999).

Although milk protein content numerically increased at a low rate with a milking interval between 4 and $20 \mathrm{~h}$, the effect was not significant for the whole 24-h period. This was a consequence of the decrease observed in milk protein content for the last 20- to 24$\mathrm{h}$ milking interval, which contrasted with the increase in milk protein content in dairy ewes for the 24-h milking interval reported by McKusick et al. (2002).

Casein does not move through leaky mammary TJ and increased slightly as milk secretion progressed by effect of a concentration process. Nevertheless, for the last 20 to $24 \mathrm{~h}$ milking interval, a decrease in $\mathrm{CN}$ content was also detected in our results, the effect not being significant for Lacaune ewes. Reduction in the $\mathrm{CN}$ and protein content in milk could be related to the passage of interstitial fluid to the milk due to TJ leakiness, resulting in a dilution effect on $\mathrm{CN}$, as well as to the increased proteolytic activity of PL.

In both breeds, true protein content increased with milking interval, reached the greatest value at 20 -h milking interval and stabilized thereafter. True protein in milk contains the proteins that are synthesized in the mammary gland (e.g., $\mathrm{CN}$ ) and the serum proteins that enter the milk when mammary $\mathrm{TJ}$ are disrupted. Therefore, in our experiment, the increase in true protein content at extended milking intervals was probably due to an increase in serum proteins in milk caused by the loss of mammary TJ integrity. The entrance of serum proteins (e.g., serum albumin) into milk as a consequence of mammary TJ disruption was previously observed in dairy cows milked once daily (Stelwagen et al., 1994a, 1997).

Milk fat content was low at longer milking intervals and milk protein content did not vary significantly, which contrasts with results obtained from long-term experiments, where reducing the milking frequency from twice to once daily resulted in greater fat and protein contents in all breeds of ewes (Tsigay, Karagouniko, Lacaune, Sarda, Manchega, and Churra) tested (Labussière, 1983). When extended milking interval is performed for long periods, the animal adapts to this situation by decreasing milk yield and concentrating milk components. Nevertheless, the milking intervals tested in the current study were performed for short-term periods, which may explain the discrepancy between short- and long-term studies.

Lactose content dramatically changed and was lowest $(P<0.05)$ at the 24 -h milking interval in Manchega and Lacaune ewes. This is in agreement with previous findings in Awassi and Merino ewes (Nudda et al., 2002 ), in which a decrease in lactose content was observed in animals exposed to once-daily milking for a short period. Lactose in milk of Manchega ewes decreased $(-3 \%, P<0.05)$ from the 20 - to 24 -h milking interval, but the effect was not significant in Lacaune ewes $(-1.5 \%)$. Decreases of milk lactose percentage seem to be due to lactose passing from milk into blood through impaired TJ (Stelwagen et al., 1994a,b, 1995) associated with extended milking intervals. As milking interval increased, the yield of milk components 
Table 2. Short-term effects of milking interval on milk volume and milk composition in Manchega and Lacaune dairy breed ewes ${ }^{1}$

\begin{tabular}{|c|c|c|c|c|c|c|c|}
\hline \multirow[b]{2}{*}{ Item } & \multicolumn{6}{|c|}{ Milking interval (h) } & \multirow[b]{2}{*}{ SEM } \\
\hline & 4 & 8 & 12 & 16 & 20 & 24 & \\
\hline \multicolumn{8}{|c|}{ Milk volume, $\mathrm{mL}$} \\
\hline Manchega & $157^{f, x}$ & $344^{\mathrm{e}, \mathrm{x}}$ & $484^{\mathrm{d}, \mathrm{x}}$ & $609^{\mathrm{c}, \mathrm{x}}$ & $701^{\mathrm{b}, \mathrm{x}}$ & $904^{\mathrm{a}, \mathrm{x}}$ & 66 \\
\hline Lacaune & $345^{\mathrm{f}, \mathrm{y}}$ & $761^{\mathrm{e}, \mathrm{y}}$ & $1,098^{\mathrm{d}, \mathrm{y}}$ & $1,436^{\mathrm{c}, \mathrm{y}}$ & $1,712^{\mathrm{b}, \mathrm{y}}$ & $2,012^{\mathrm{a}, \mathrm{y}}$ & 66 \\
\hline \multicolumn{8}{|c|}{ Milk composition, \% } \\
\hline \multicolumn{8}{|c|}{ Fat } \\
\hline Manchega & $8.52^{\mathrm{a}, \mathrm{x}}$ & $8.22^{\mathrm{ab}, \mathrm{x}}$ & $8.01^{\mathrm{ab}, \mathrm{x}}$ & $7.94^{\mathrm{bc}, \mathrm{x}}$ & $7.58^{\mathrm{c}, \mathrm{x}}$ & $6.97^{\mathrm{d}, \mathrm{x}}$ & 0.23 \\
\hline Lacaune & $7.50^{\mathrm{a}, \mathrm{y}}$ & $6.70^{\mathrm{b}, \mathrm{y}}$ & $6.61^{\mathrm{b}, \mathrm{y}}$ & $6.41^{\mathrm{b}, \mathrm{y}}$ & $6.30^{\mathrm{b}, \mathrm{y}}$ & $5.86^{\mathrm{c}, \mathrm{y}}$ & 0.22 \\
\hline \multicolumn{8}{|l|}{ Protein } \\
\hline Manchega & $6.07^{\mathrm{x}}$ & $6.26^{\mathrm{x}}$ & $6.32^{\mathrm{x}}$ & $6.36^{\mathrm{x}}$ & $6.48^{\mathrm{x}}$ & $6.24^{\mathrm{x}}$ & 0.11 \\
\hline Lacaune & $5.68^{\mathrm{y}}$ & $5.59^{\mathrm{y}}$ & $5.68^{\mathrm{y}}$ & $5.68^{\mathrm{y}}$ & $5.73^{\mathrm{y}}$ & $5.59^{\mathrm{y}}$ & 0.11 \\
\hline \multicolumn{8}{|l|}{ Casein } \\
\hline Manchega & $4.54^{\mathrm{c}, \mathrm{x}}$ & $4.78^{\mathrm{b}, \mathrm{x}}$ & $4.87^{\mathrm{ab}, \mathrm{x}}$ & $4.90^{\mathrm{ab}, \mathrm{x}}$ & $5.02^{\mathrm{a}, \mathrm{x}}$ & $4.81^{\mathrm{b}, \mathrm{x}}$ & 0.09 \\
\hline Lacaune & $4.31^{\mathrm{y}}$ & $4.30^{\mathrm{y}}$ & $4.38^{\mathrm{y}}$ & $4.36^{\mathrm{y}}$ & $4.40^{\mathrm{y}}$ & $4.26^{\mathrm{y}}$ & 0.09 \\
\hline \multicolumn{8}{|l|}{ True protein } \\
\hline Manchega & $5.58^{\mathrm{c}, \mathrm{x}}$ & $5.79^{\mathrm{bc}, \mathrm{x}}$ & $5.84^{\mathrm{b}, \mathrm{x}}$ & $5.87^{\mathrm{ab}, \mathrm{x}}$ & $6.04^{\mathrm{a}, \mathrm{x}}$ & $6.02^{\mathrm{ab}, \mathrm{x}}$ & 0.12 \\
\hline Lacaune & $5.24^{\mathrm{abc}, \mathrm{y}}$ & $5.07^{\mathrm{c}, \mathrm{y}}$ & $5.37^{\mathrm{ab}, \mathrm{y}}$ & $5.28^{\mathrm{b}, \mathrm{y}}$ & $5.47^{\mathrm{a}, \mathrm{y}}$ & $5.32^{\mathrm{ab}, \mathrm{y}}$ & 0.11 \\
\hline \multicolumn{8}{|l|}{ Lactose } \\
\hline Manchega & $4.72^{\mathrm{ab}}$ & $4.76^{\mathrm{ab}}$ & $4.77^{\mathrm{a}}$ & $4.83^{\mathrm{a}}$ & $4.81^{\mathrm{a}}$ & $4.68^{\mathrm{b}}$ & 0.19 \\
\hline Lacaune & $4.82^{\mathrm{a}}$ & $4.74^{\mathrm{ab}}$ & $4.76^{\mathrm{ab}}$ & $4.72^{\mathrm{ab}}$ & $4.75^{\mathrm{ab}}$ & $4.68^{\mathrm{b}}$ & 0.26 \\
\hline \multicolumn{8}{|l|}{ Total solids } \\
\hline Manchega & $21.5^{\mathrm{a}, \mathrm{x}}$ & $20.5^{\mathrm{ab}, \mathrm{x}}$ & $20.0^{\mathrm{b}, \mathrm{x}}$ & $20.1^{\mathrm{b}, \mathrm{x}}$ & $19.6^{\mathrm{bc}, \mathrm{x}}$ & $18.9^{\mathrm{c}, \mathrm{x}}$ & 0.45 \\
\hline Lacaune & $18.9^{\mathrm{a}, \mathrm{y}}$ & $17.6^{\mathrm{b}, \mathrm{y}}$ & $17.6^{\mathrm{b}, \mathrm{y}}$ & $17.6^{\mathrm{b}, \mathrm{y}}$ & $17.6^{\mathrm{b}, \mathrm{y}}$ & $17.1^{b, y}$ & 0.43 \\
\hline \multicolumn{8}{|c|}{$\mathrm{SCC}, \log _{10}$ cells $/ \mathrm{mL}$} \\
\hline Manchega & $5.14^{\mathrm{b}}$ & $5.53^{\mathrm{a}}$ & $5.35^{\mathrm{b}}$ & $5.39^{\mathrm{ab}}$ & $5.32^{\mathrm{b}}$ & $5.23^{\mathrm{b}}$ & 0.10 \\
\hline Lacaune & $5.05^{\mathrm{b}}$ & $5.26^{\mathrm{a}}$ & $5.28^{\mathrm{a}}$ & $5.13^{\mathrm{ab}}$ & $5.15^{\mathrm{ab}}$ & $5.08^{\mathrm{b}}$ & 0.10 \\
\hline
\end{tabular}

${ }^{\mathrm{a}-\mathrm{f}}$ Means with different superscripts within a row differ $(P<0.05)$.

${ }^{\mathrm{x}, \mathrm{y}}$ Means with different superscripts within a column for each item differ $(P<0.05)$.

${ }^{1}$ Values are least squares means.

increased significantly in both breeds in accordance with the increase in milk yield (data not shown).

Milk SCC was similar $(P>0.10)$ between ewes of both breeds, which showed a very low level of SCC at all milking intervals tested (211 and $144 \times 10^{3}$ cells/ $\mathrm{mL}$ on average, respectively), indicating that sheep udders were healthy and were not affected by different milking intervals in a short period. Nevertheless, milk SCC values (Table 2$)$ varied slightly $(P<0.001)$ with milking interval. The greatest logSCC in milk was observed at 8-h milking interval in Manchega and at 8 to $12 \mathrm{~h}$ in Lacaune, probably due to a concentration effect. Our results are in agreement with other studies conducted in dairy ewes (McKusick et al., 2002) and dairy goats (Salama et al., 2003), where milk obtained at short milking intervals had slightly greater $\operatorname{logSCC}$ values.

\section{Plasmin Activity}

The milk PL activity for the experimental milking intervals was similar in both breeds (Figure 3) and averaged $6.90 \pm 0.86 \mathrm{units} / \mathrm{mL}$ in Manchega and 5.15 \pm 1.24 units $/ \mathrm{mL}$ in Lacaune ewes. Our data are lower than those found for ewes' milk in previous studies
(Bianchi et al., 2004; Albenzio et al., 2005). These differences could be at least partly explained by diversity of SCC levels and stages of lactation of the animals

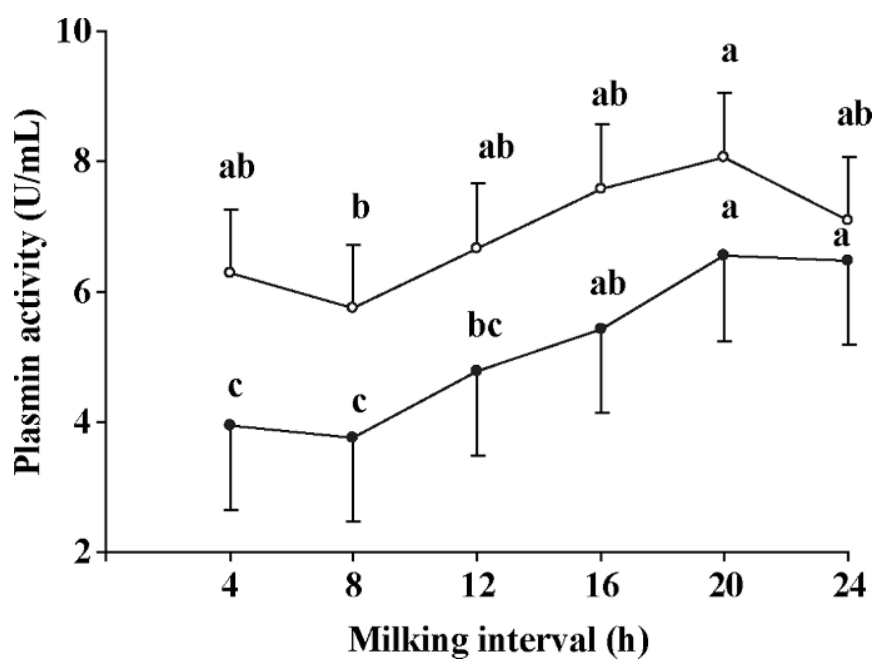

Figure 3. Plasmin activity with 4-, 8-, 12-, 16-, 20-, and 24-h milking intervals in Manchega $(\bigcirc)$ and Lacaune $(\bullet)$ dairy ewes. Values are least squares means. ${ }^{a-c}$ Means within the same breed with different letters differ at $P<0.05$; vertical bars represent SEM. 
used in each experiment, because PL activity in ewes' milk was reported to be markedly affected by SCC and stage of lactation (Albenzio et al., 2004, 2005; Bianchi et al., 2004).

Milking interval affected $(P<0.05)$ PL activity in the milk of both breeds, which is in agreement with results shown in dairy cows by Stelwagen et al. (1994c) and Kelly et al. (1998), where the increase of milking interval increased PL activity. However, Klei et al. (1997) and O'Brien et al. (2002) did not find significant effects of different milking frequencies on PL concentrations in dairy cows.

In our case, PL activity increased with milking interval up to $20 \mathrm{~h}$ for both ewe breeds and stabilized thereafter. The PL activity may be augmented either by increasing leakage from blood or by conversion of plasminogen from blood to plasmin in milk (Politis et al., 1989). It appears likely that, in our study, the increase in PL activity was the result of an enhanced influx of enzyme from the blood to the milk across damaged TJ, when extended milking intervals were performed (see discussion below).

A low and negative correlation between milk yield and PL activity ( $\mathrm{r}=-0.18 ; P<0.05)$ was observed. This may be related to the fact that ewes with greater milk yield usually have larger cisterns and are more tolerant to longer milking intervals (Labussière, 1988; Rovai, 2001). Therefore, it is possible that they do not suffer a high TJ leakiness and consequently, the plasminogen and PL entrance from the blood into the milk in large-cisterned ewes is less marked than in ewes with smaller cisterns.

On the contrary, positive correlations were observed between PL and SCC $(\mathrm{r}=0.39 ; P<0.001)$ in agreement with previous findings in sheep (Albenzio et al., 2004), bovine (Politis et al., 1989; Baldi et al., 1996), and goat milk (Fantuz et al., 2001). Milk protein $(\mathrm{r}=0.40 ; P<$ $0.001), \mathrm{CN}(\mathrm{r}=0.37 ; P<0.001)$, and true protein $(\mathrm{r}=$ $0.40 ; P<0.001)$ contents also correlated positively with $\mathrm{PL}$ activity. It is well known that plasminogen and plasminogen activators are associated with $\mathrm{CN}$ micelles (Richardson, 1983). Thus, it may be hypothesized that the greater the $\mathrm{CN}$ content, the greater the amount of plasminogen activator that remains bound into the micelles and converts the plasminogen to $\mathrm{PL}$ (Albenzio et al., 2004).

\section{TJ Permeability}

Results described above suggest the impairment of TJ as one of the main causes of variations in milk secretion rate and milk composition when extended milking intervals are performed. To confirm this hypothesis, lactose concentration in plasma and mineral concentration ( $\mathrm{Na}$ and $\mathrm{K}$ ) in milk were used as indicators of the state of TJ (Table 3 and Figure 4) as indicated by Stelwagen et al. (1994a,b).

Lactose in plasma was considered the main indicator of mammary TJ permeability in the present study because changes in $\mathrm{Na}$ and $\mathrm{K}$ concentrations may simply reflect an alteration in the transport of these ions across transcellular rather than paracellular pathways.

Our results did not show interbreed differences in lactose concentration in plasma $(11.9 \pm 6.3 \mu \mathrm{mol} / \mathrm{L}$ on average; $P=0.35$ ) because of the high variability of lactose analyses. Stage of lactation tended to affect $(P=$ $0.07)$ the concentration of lactose in plasma. Average concentration of lactose at wk $11(15.7 \pm 5.3 \mu \mathrm{mol} / \mathrm{L})$ tended to be greater than at wk $16(8.1 \pm 5.3 \mu \mathrm{mol} / \mathrm{L})$. Udder distension was greater in the first experimental period than in the second one because of the greater milk production. This fact seemed to favor the TJ impairment during this period.

Milking interval affected $(P<0.01)$ lactose concentration in plasma (Figure 4). In both breeds the concentration of lactose in plasma was somewhat steady until $20 \mathrm{~h}$, when it dramatically increased. In the 20- to 24$\mathrm{h}$ interval, plasma lactose in Manchega increased by 5 -fold (5.2 to $26.7 \mu \mathrm{mol} / \mathrm{L} ; P<0.01$ ), whereas in Lacaune it increased by only 1.5 -fold (19.1 to $27.8 \mu \mathrm{mol} /$ $\mathrm{L} ; P=0.28$ ), indicating that the TJ leakiness effect was greater in Manchega than in Lacaune ewes. Our results showed that TJ became disrupted after $20 \mathrm{~h}$ of udder filling in dairy ewes, but this effect was more marked in Manchega ewes. No previous data are available on the timing of TJ opening during extended milking intervals in dairy ewes.

In previous studies, TJ were leaky after $20 \mathrm{~h}$ in dairy goats (Stelwagen et al., 1994b), whereas TJ were leaky earlier (18 h) in dairy cows (Stelwagen et al., 1997), in accordance with the lower cisternal capacity in dairy cows compared with goats.

Ewe breed affected $(P<0.01) \mathrm{Na}$ and $\mathrm{K}$ concentration in milk (Table 3). Manchega showed, on average, greater $\mathrm{Na}$ concentration $(21.0 \pm 1.2$ vs. $16.6 \pm 1.2$ $\mathrm{mmol} / \mathrm{L} ; P<0.01)$ and lower $\mathrm{K}$ concentration $(29.7 \pm$ 0.8 vs. $35.0 \pm 0.8 \mathrm{mmol} / \mathrm{L} ; P<0.001)$ than Lacaune ewes. Interaction of breed $\times$ milking interval was significant $(P<0.05)$ for $\mathrm{Na}$ concentration and $\mathrm{Na}$ :K ratio. The Na concentration in milk for Manchega ewes was steady until $20 \mathrm{~h}$ and increased markedly thereafter (Table 3). Milking interval did not modify $\mathrm{Na}$ content in milk for Lacaune ewes. Only slight changes were observed for $\mathrm{K}$ values in milk of Manchega, obtaining the lowest value with a 24-h interval in Manchega. No changes were observed for Lacaune ewes. Moreover, a greater $\mathrm{Na}: \mathrm{K}$ ratio in the milk was observed at ex- 
Table 3. Effect of different milking intervals $(4,8,12,16,20$, and $24 \mathrm{~h})$ on the concentration of $\mathrm{Na}, \mathrm{K}$ and the $\mathrm{Na}$ to $\mathrm{K}$ ratio in the milk of Manchega and Lacaune breeds ${ }^{1}$

\begin{tabular}{|c|c|c|c|c|c|c|c|}
\hline \multirow[b]{2}{*}{ Item } & \multicolumn{6}{|c|}{ Milking interval (h) } & \multirow[b]{2}{*}{ SEM } \\
\hline & 4 & 8 & 12 & 16 & 20 & 24 & \\
\hline \multicolumn{8}{|l|}{$\mathrm{Na}, \mathrm{mmol} / \mathrm{L}$} \\
\hline Manchega & $19.47^{\mathrm{c}}$ & $19.86^{\mathrm{c}}$ & $19.91^{\mathrm{c}}$ & $20.88^{\mathrm{c}}$ & $22.18^{\mathrm{b}}$ & $23.73^{\mathrm{a}}$ & 1.23 \\
\hline Lacaune & 16.85 & 16.01 & 16.23 & 17.06 & 16.62 & 16.75 & 1.23 \\
\hline \multicolumn{8}{|l|}{$\mathrm{K}, \mathrm{mmol} / \mathrm{L}$} \\
\hline Manchega & $28.79^{\mathrm{bc}}$ & $30.90^{\mathrm{a}}$ & $30.90^{\mathrm{a}}$ & $29.08^{\mathrm{bc}}$ & $30.35^{\mathrm{ab}}$ & $28.41^{\mathrm{c}}$ & 0.97 \\
\hline Lacaune & 33.14 & 35.30 & 35.39 & 35.53 & 35.36 & 34.70 & 0.97 \\
\hline \multicolumn{8}{|l|}{$\mathrm{Na}: \mathrm{K}$} \\
\hline Manchega & $0.70^{\mathrm{bc}}$ & $0.65^{\mathrm{c}}$ & $0.66^{\mathrm{c}}$ & $0.76^{\mathrm{b}}$ & $0.76^{\mathrm{b}}$ & $0.86^{\mathrm{a}}$ & 0.05 \\
\hline Lacaune & 0.52 & 0.46 & 0.46 & 0.49 & 0.49 & 0.50 & 0.05 \\
\hline
\end{tabular}

${ }^{\mathrm{a}-\mathrm{c}}$ Means with different superscripts within row differ $(P<0.05)$.

${ }^{1}$ Values are least squares means.

tended milking intervals in Manchega ewes, whereas in Lacaune this ratio was constant (Table 3). The $\mathrm{Na}$ and $\mathrm{K}$ balance between alveolar and blood compartments is controlled by TJ. Therefore, an increase in $\mathrm{Na}$ concentration and $\mathrm{Na}: \mathrm{K}$ ratio in milk of Manchega should be a consequence of TJ opening at extended milking intervals, in accordance with the increased plasma lactose values observed (Figure 4). To our knowledge, this finding has not been reported before in dairy sheep. Despite the TJ leakiness after $20 \mathrm{~h}$ in Lacaune ewes (Figure 4), no changes in $\mathrm{Na}$ and $\mathrm{K}$ concentrations were detected at extended milking intervals. The degree of TJ leakiness in Lacaune ewes was not sufficient to induce significant changes in ion transport from blood to milk and vice versa. The greater Na:K ratio in the milk from udders milked less frequently in Manchega breed in our study agreed with

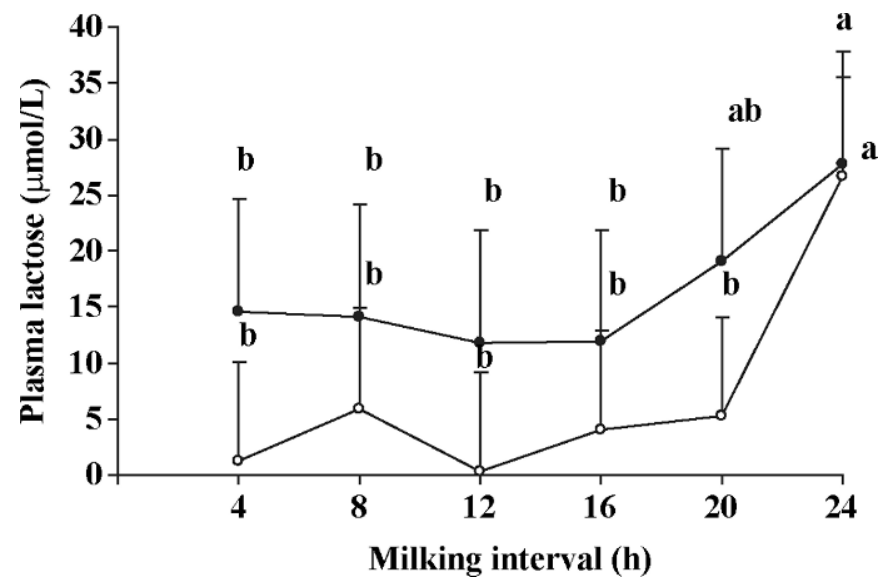

Figure 4. Plasma lactose concentrations obtained 4, 8, 12, 16, 20, and $24 \mathrm{~h}$ after the last milking. Values are least squares means \pm SEM for 8 dairy ewes of Manchega $(n=4$; $\bigcirc)$ and Lacaune $(n=4$; -) breed. ${ }^{\mathrm{a}, \mathrm{b}}$ Means within the same breed with different letters differ at $P<0.05$; vertical bars represent SEM. previous reports in dairy goats (Stelwagen et al., 1994b, 1997) and in dairy cows (Lacy-Hulbert et al., 1999).

Stelwagen et al. (1999) showed that the adverse effects of Na variations on milk secretion were not due to a high intracellular concentration of $\mathrm{Na}$ per se. Thus, either an increase or a reduction in the $\mathrm{Na}: \mathrm{K}$ ratio was related to a low milk secretion. Therefore, in our experiment, the increase of the $\mathrm{Na}: \mathrm{K}$ ratio after the 16-h milking interval in Manchega ewes could also explain the decrease of milk secretion rate observed at $20 \mathrm{~h}$ of udder filling (Figure 2). Furthermore, the fact that variations in ion concentration were only significant in the Manchega ewe milk allow us to suggest that udders of Manchega ewes had a lower capacity for adaptation to extended milking intervals and greater TJ leakiness compared with Lacaune ewes.

\section{CONCLUSIONS}

Manchega and Lacaune dairy ewes were able to tolerate extended milking intervals during short-term experiments, maintaining linear increases of milk production up to $24 \mathrm{~h}$ of udder filling with no negative effects on udder health. However, milk secretion rate and milk composition varied in extended milking intervals, especially in the case of milk fat and milk lactose, partly as a consequence of paracellular leakage across the mammary epithelium. Furthermore, the present experiment demonstrates that TJ disruption occurs in dairy sheep after $20 \mathrm{~h}$ of milk accumulation, as reported earlier in goats. However, degree of TJ leakiness differed according to breed, being more pronounced in Manchega (small udder cisterns) than in Lacaune ewes (large udder cisterns). Dairy ewes may be able to support $20 \mathrm{~h}$ of udder filling without negative effects on milk yield or milk composition, making possible the use of once-a-day or occasional 
milking omission schedules. Nevertheless, further long-term studies are required.

\section{ACKNOWLEDGMENTS}

This work is part of a CICYT research project (AGL2002-03472) of the Spanish Ministry of Science and Technology. The authors are grateful to Ramon Costa and the team of the SGCE (Servei de Granges i Camps Experimentals) of the Universitat Autònoma de Barcelona for the care of the animals and to Nic Aldam for the English revision of the manuscript.

\section{REFERENCES}

Albanell, E., P. Cáceres, G. Caja, E. Molina, and A. Gargouri. 1999. Determination of fat, protein, and total solids in ovine milk by near-infrared spectroscopy. J. AOAC Int. 82:753-758.

Albenzio, M., M. Caroprese, A. Santillo, R. Marino, A. Muscio, and A. Sevi. 2005. Proteolytic patterns and plasmin activity in ewes' milk as affected by somatic cell count and stage of lactation. J. Dairy Res. 72:86-92.

Albenzio, M., M. Caroprese, A. Santillo, R. Marino, L. Taibi, and A. Sevi. 2004. Effects of somatic cell count and stage of lactation on the plasmin activity and cheese-making properties of ewe milk. J. Dairy Sci. 87:533-542.

Ayadi, M., G. Caja, X. Such, and C. H. Knight. 2003a. Use of ultrasonography to estimate cistern size and milk storage at different milking intervals in the udder of dairy cows. J. Dairy Res. 70:1-7.

Ayadi, M., G. Caja, X. Such, and C. H. Knight. 2003b. Effect of omitting one milking weekly on lactational performances and morphological udder changes in dairy cows. J. Dairy Sci. 86:2352-2358.

Baldi, A., G. Savoini, F. Cheli, F. Fantuz, E. Senatore, L. Bertocchi, and I. Politis. 1996. Changes in plasmin-plasminogen-plasminogen activator system in milk from Italian friesian herds. Int. Dairy J. 6:1045-1053.

Bastian, E. D., and R. J. Brown. 1996. Plasmin in milk and dairy products: An update. Int. Dairy J. 6:435-457.

Bianchi, L., A. Bolla, E. Budelli, A. Caroli, C. Casoli, M. Pauselli, and E. Duranti. 2004. Effect of udder health status and lactation phase on the characteristics of Sardinian ewe milk. J. Dairy Sci. 87:2401-2408.

Davis, S. R., V. C. Farr, and K. Stelwagen. 1999. Regulation of yield loss and milk composition during once-daily milking: A review. Livest. Prod. Sci. 59:77-94.

Dubeuf, J. P., and J. C. Le Jaouen. 2005. The sheep and goat dairy sectors in the European Union: Present situation and stakes for the future. Pages 1-6 in Special Issue of the International Dairy Federation 0501/Part 1. Future of the sheep and goats dairy sectors. Zaragoza, Spain.

Fantuz, F., F. Polidori, F. Cheli, and A. Baldi. 2001. Plasminogen activation system in goat milk and its relation with composition and coagulation properties. J. Dairy Sci. 84:1786-1790.

Hernández, L. L., C. M. Stiening, J. B. Wheelock, L.H. Baumgard, A. M. Parkhurst, and R. J. Collier. 2008. Evaluation of serotonin as a feedback inhibitor of lactation in the bovine. J. Dairy Sci. 91:1834-1844.

Kelly, A. L., S. Reid, P. Joyce, W. J. Meaney, and J. Foley. 1998. Effect of decreased milking frequency of cows in late lactation on milk somatic cell count, polymorphonuclear leucocyte numbers, composition and proteolytic activity. J. Dairy Res. 65:365-373.

Klei, L. R., J. M. Lynch, D. M. Barbano, P. A. Oltenacu, A. J. Lednor, and D. K. Bandler. 1997. Influence of milking three times a day on milk quality. J. Dairy Sci. 80:427-436.

Knight, C. H., and R. J. Dewhurst. 1994. Once daily milking of dairy cows: Relationship between yield loss and cisternal milk storage. J. Dairy Res. 61:441-449.
Knight, C. H., D. Hirst, and R. J. Dewhurst. 1994. Milk accumulation and distribution in the bovine udder during the interval between milkings. J. Dairy Res. 61:167-177.

Kuhn, N., and J. L. Linzell. 1970. Measurement of the quantity of lactose passing into mammary venous plasma and lymph in goats and in a cow. J. Dairy Res. 37:203-208.

Labussière, J. 1983. Projet d'étude des caractéristiques de traite des differéntes races de brebis laitières exploitées dans de bassin méditerranéen. III Symposium Internacional de ordeño mecánico de pequeños rumiantes, Valladolid, 730-768.

Labussière, J. 1988. Review of physiological and anatomical factors influencing the milking ability of ewes and the organization of milking. Livest. Prod. Sci. 18:253-274.

Lacy-Hulbert, S. J., M. W. Woolford, G. D. Nicholas, C. G. Prosser, and K. Stelwagen. 1999. Effect of milking frequency and pasture intake on milk yield and composition of late lactation cows. J. Dairy Sci. 82:1232-1239.

Marnet, P. G., and B. C. McKusick. 2001. Regulation of milk ejection and milkability in small ruminants. Livest. Prod. Sci. 70:125133.

McKusick, B. C., D. L. Thomas, Y. M. Berger, and P. G. Marnet. 2002. Effect of milking interval on alveolar versus cisternal milk accumulation and milk production and composition in dairy ewes. J. Dairy Sci. 85:2197-2206.

Mills, O. 2004. Sheep husbandry. Milking management. Pages 2507-2517 in Encyclopedia of Dairy Sciences. H. Roginski, ed. Academic Press, Amsterdam, the Netherlands.

Morag, M. 1968. The effect of varying the daily milking frequency on the milk yield of the ewe and evidence on the nature of the inhibition of milk ejection by half-udder milking. Ann. Zootech. 17:351-369.

Negrao, J. A., P. G. Marnet, and J. Labussière. 2001. Effect of milking frequency on oxytocin release and milk production in dairy ewes. Small Rumin. Res. 39:181-187.

Nudda, A., R. Bencini, S. Mijatovic, and G. Pulina. 2002. The yield and composition of milk in Sarda, Awassi, and Merino sheep milked unilaterally at different frequencies. J. Dairy Sci. 85:2879-2884.

O'Brien, B., G. Ryan, W. J. Meaney, D. McDonagh, and A. Kelly. 2002. Effect of frequency of milking on yield, composition and processing quality of milk. J. Dairy Res. 69:367-374.

Politis, I., E. Lachance, E. Block, and J. D. Turner. 1989. Plasmin and plasminogen in bovine milk: A relationship with involution? J. Dairy Sci. 72:900-906.

Richardson, B. C. 1983. The proteinases of bovine milk and the effect of pasteurization on their activity. N.Z. J. Dairy Sci. Technol. 18:233-245.

Rovai, M. 2001. Caracteres morfológicos y fisiológicos que afectan la aptitud al ordeño mecánico en ovejas de raza Manchega y Lacaune. Doctoral thesis. Universidad Autónoma de Barcelona, Spain.

Salama, A. A. K., G. Caja, X. Such, S. Peris, A. Sorensen, and C. H. Knight. 2004. Changes in cisternal udder compartment induced by milking interval in dairy goats milked once or twice daily. J. Dairy Sci. 87:1181-1187.

Salama, A. A. K., X. Such, G. Caja, M. Rovai, R. Casals, E. Albanell, M. P. Marín, and A. Martí. 2003. Effects of once versus twice daily milking throughout lactation on milk yield and milk composition in dairy goats. J. Dairy Sci. 86:1673-1680.

Stelwagen, K., S. R. Davis, V. C. Farr, and S. J. Eichler. 1994a. Effect of once daily milking and concurrent somatotropin on mammary tight junction permeability and yield of cows. J. Dairy Sci. 77:2994-3001.

Stelwagen, K., S. R. Davis, V. C. Farr, C. G. Prosser, and R. A Sherlock. 1994b. Mammary epithelial cell tight junction integrity and mammary blood flow during an extended milking interval in goats. J. Dairy Sci. 77:426-432.

Stelwagen, K., V. C. Farr, S. R. Davis, and C. G. Prosser. 1995. EGTA-induced disruption of epithelial cell tight junctions in the lactating caprine mammary gland. Am. J. Physiol. 269:R848R855. 
Stelwagen, K., V. C. Farr, and H. A. McFadden. 1999. Alteration of the sodium to potassium ratio in milk and effect on milk secretion in goats. J. Dairy Sci. 88:52-59.

Stelwagen, K., V. C. Farr, H. A. McFadden, C. G. Prosser, and S. R. Davis. 1997. Time course of milk accumulation-induced opening of mammary tight junctions and blood clearance of milk components. Am. J. Physiol. 273:R379-R386.

Stelwagen, K., R. D. McLaren, S. A. Turner, H. A. McFadden, and C. G. Prosser. 1998. No evidence for basolateral secretion of milk protein in the mammary gland of lactating goats. J. Dairy Sci. 81:434-437.
Stelwagen, K., I. Politis, J. H. White, B. Zavizion, C. G. Prosser, S. R. Davis, and V. C. Farr. 1994c. Effect of milking frequency and somatotropin on the activity of plasminogen activator, plasminogen, and plasmin in bovine milk. J. Dairy Sci. 77:3577-3583.

Such, X., G. Caja, L. Pérez, and S. Peris. 1995. Primeros resultados de la comparación de la aptitud al ordeño mecánico de ovejas Lacaune y Manchega: 1. Estudio del fraccionamiento de leche y la morfología mamaria. ITEA Prod. Anim. 16:708-710.

Wilde, C. J., C. V. P. Addey, L. M. Boddy, and M. Peaker. 1995. Autocrine regulation of milk secretion by a protein in milk. Biochem. J. 305:51-58. 